\title{
THE IMPLEMENTATION OF S.U.R.E. APPROACH AS A MEANS OF ENHANCING STUDENTS' PRAGMATIC COMPETENCE
}

\author{
Dasep Suprijadi \\ suprijadi.dasep17@gmail.com \\ English Department, IKIP Siliwangi, Bandung- Indonesia
}

\begin{abstract}
Due to the deficient pragmatic competence, pragmatic failures or even miscommunication will be produced in actual communication. Regarding those problems, S.U.R.E approach is offered to overcome in promoting learners' pragmatic competence. This study aimed to investigate the impact of implementing S.U.R.E approach in improving students' pragmatic competence. This study is a quantitative research embracing one group pretest-posttest design. One class participated and 33 students were taken as the sample of the study using random sampling technique. Three English native speakers evaluated the test takers' pragmatic competence. They were called on to read the speech acts, along with the transcripts, and to indicate the rating based on the rating descriptions provided. The mean score among the three raters was assigned as the closing score. To collect the data, the students were given a pretest and a posttest. The data were then analyzed employing paired sample t-test through SPSS V.24. The result of the study showed that significance value was 0.00 of which it is lower than level of significance 0.05 . Hence, the null hypothesis is rejected. This implies that the use of S.U.R.E approach has a significant effect on improving students' pragmatic competence.
\end{abstract}

Keywords: Pragmatics, Pragmatic Competence, EFL Students, S.U.R.E Approach,

\section{Sari}

Karena kompetensi pragmatis yang tidak baik, kegagalan pragmatis atau bahkan gangguan komunikasi akan benar-benar terjadi.. Menghadapi permasalahan tersebut, pendekatan S.U.R.E ditawarkan sebagai jalan keluar dalam meningkatkan kompetensi pragmatis peserta didik. Tujuan dari penelitian ini adalah untuk menyelidiki pengaruh penggunaan pendekatan S.U.R.E pada peningkatan kompetensi pragmatis siswa. Ini adalah penelitian kuantitatif dengan desain satu kelompok pretest-posttest. Satu kelas dilibatkan dan 33 siswa diambil sebagai sampel penelitian menggunakan teknik random sampling. Tiga penutur asli Bahasa Inggris mengevaluasi kompetensi pragmatis peserta tes. Mereka diminta untuk membaca tindak tutur, bersama dengan transkrip, dan untuk menunjukkan peringkat berdasarkan deskripsi peringkat yang disediakan. Skor rata-rata antara tiga penilai dijadikan sebagai skor akhir. Untuk mengumpulkan data, siswa diberi pretest dan posttest. Data kemudian dianalisis menggunakan paired sample t-test melalui SPSS V.24. Hasil penelitian menunjukkan bahwa nilai signifikansi 0,00 yang 
lebih rendah dari tingkat signifikansi 0,05 . Oleh karena itu, hipotesis nol ditolak. Ini menyiratkan bahwa penggunaan pendekatan S.U.R.E memiliki efek signifikan pada peningkatan kompetensi pragmatis siswa.

Kata kunci: Kompetensi Pragmatis, Pendekatan S.U.R.E

Received 2020-07-31 accepted 2020-09-30 published 2020-09-30

APA Citation: Suprijadi, D. (2020). THE IMPLEMENTATION OF S.U.R.E. APPROACH AS A MEANS OF ENHANCING STUDENT PRAGMATIC COMPETENCE. Research and Innovation in Language Learning 3(3), pp. 197-207 http://dx.doi.org/10.33603/rill.v3i3.3962

\section{Introduction}

The existence of communicative approach has shifted the position of learning English as a foreign or as a second language. This means that learning English which initially emphasized linguistic and grammatical accuracy, nowadays, since the use of the communicative approach, has changed to English learning which emphasizes mastery of English functional abilities. The ultimate goal of learning based on this communicative approach is to understand and produce English that is in line with the sociocultural norms of the native English speaking community (Rueda, 2006; Liu, 2007). This is in line with the general view which states that the most important goal of language learning, in this case English, is to achieve student communicative competence and one of the important parts of communicative competence is pragmatic competence, which is interpreted as the ability to use English according to context (Tan \& Farashaiyan, 2012; Richard, 2006).

Nevertheless, pragmatic competence is rarely included in various discussions in English language instruction in classrooms. Even though the teaching of pragmatic competence is very essential for sustainable professional development (Vellenga, 2011). Therefore, as the impacts, the students' pragmatic competence tends to be low. Hence, EFL teachers should be aware that this could be the consequence of not bringing this very important competence to English classrooms. As a result of neglecting the prominence of highlighting pragmatic competence in the teaching of English, the inability of English students appeared e.g. in interpreting discourse according to its context as well as in understanding what English users intended in a communication they experienced (Bachman \& Palmer in Yuan, 2012). 
Pragmatic competence is interpreted as the competence of English students to use English language, especially spoken English, in accordance with the context related to the socio-culture of native English speakers. In this case, EFL learners should be able to understand and master two elements of pragmatic competence, namely pragmalinguistics and socio-pragmatics. The first type of competency refers to the realization of linguistics to produce certain language acts or communicative acts, while the next type of competence is closely related to the appropriate use of English from the form or it is a linguistic realization based on context, the very important role of each individual in that context, and the politeness elements of social distance, the imposition degree and the power of persons getting involved in a communication (Brown \& Levinson, 1987). To enhance students' pragmatic competence, teachers are suggested to implement appropriate teaching approaches. In this present study, the researcher chose S.U.R.E approach to solve the lack of pragmatic competence problem. Thus, this attempts to test the following hypothesis:

$\mathrm{H}_{0}$ : S.U.R.E approach is not effective to enhance students' pragmatic competence.

\section{S.U.R.E. approach}

\section{See}

In order to teach pragmatic competence to EFL learners, English teachers can try to implement several teaching approaches or techniques that lead EFL students to English pragmatic competence. In this study, the researcher applied one of the pragmatic teaching techniques called the SURE approach recommended by Brock and Nagasaka (2005). The acronym SURE is a learning technique that emphasizes the importance of mastering pragmatic competence. This pragmatic competence learning technique can be used by English teachers to guide students on how to see, use, review, and experience pragmatic competence in the teaching and learning process in the classroom.

\section{See}

EFL learners are directed to be able to see English directly in its context. They are assisted by the teacher to focus more on pragmatic situations and gain an understanding of the role of pragmatic features in typical communicative situations. In order to develop students' pragmatic awareness, the teacher can train and guide them on various 
examples of speech acts such as making requests, giving opinions, and so on. This is where the role of the English teacher is needed to be able to develop students' pragmatic competences. The existence and expertise of teachers in introducing pragmatic competences are really helpful and highly expected by students to be able to internalize pragmatic competences (Farahian, Rezaee, \& Gholami, 2012)

\section{Use}

In accordance with their understanding of digested situations in class activities, EFL students are assisted through activities that their English teachers develop to use English in its context either by simulated or real. Students practice to communicate or interact so that they have communicative competence which is the goal of learning English. Therefore, the English teacher must be able to create and provide opportunities for the use of English through group activities or pair works in the teaching and learning process.

It is believed that students' communicative abilities which are the objectives of learning in general can be achieved through group activities. Group work is an effective way to train EFL students to put what they have in mind in English; understand what other people want through the English spoken; and understand their views about something (Jonsson, 2011). Speaking which is grammatically correct and in accordance with the existing situation or context are two things that are the spirit of the communicative competence or communicative abilities that EFL students are trying to achieve.

\section{Review}

Pragmatic competence studies that have been introduced and trained to EFL students, should be reviewed, strengthened, and recycled by the English teacher. However, at this stage, the English teacher is not allowed to use L1 in the teaching and learning process and in daily communication. This is understandable because of the limited possibilities, in the EFL context, of the use of English for communicative purposes. It means that the teacher must make every effort to always use English in communication events in the EFL classroom, so that it can strengthen the development of students' pragmatic competence and understanding. 


\section{Experience}

In this stage, EFL students can be directed to experience and identify the pragmatic elements that play a role in interactions. This will be easily obtained through learning resources that are rich in the role of pragmatic competence in communication. English teachers can take advantage of learning resources that are rich in pragmatic elements that are easily observable such as videos, films, TV shows, or other video programs. Thus EFL students will easily experience and analyze the use of language in accordance with the context. Alternatively, EFL students can be directed to communicate or observe native English speakers around them. Periodically, native English speakers can be invited to attend EFL classrooms, so that their presence can help students to observe the language used or the behavior and customs of the native English speakers.

\section{Research Methods}

This research used quantitative as method embracing pre-experimental as design. Quantitative study is concerned with the measurement and data quantification, often deriving from an underlying hypothetic-deductive approach to a research question, i.e. attempting to test out an established theoretical viewpoint (Brewerton, \& Millward, 2001). In addition, (Creswell, 2014) states that quantitative research problems require that researchers explain how one variable affects another. This study utilized one group pretest and posttest design, including a pretest measure followed by a treatment and a posttest for a single group. Here is the design of one group pretest-posttest proposed by Creswell (2003).

\section{Population and Sample}

One of the first steps in designing quantitative research is to choose the subjects referring to the individuals who participate in the study from which the data are collected. As a group, subjects are usually referred to as sample. The sample can be selected from a larger group of persons, identified as the population (McMillan, \& Schumacher, 2001). In other words, population is any group that a researcher is trying to represent, whereas sample refers to any group on which information is obtained (Hamied, 2017). Hence, the research population was the first year students of a private 
university in Bandung, whereas the sample was Class $\mathrm{C}$ taken using random sampling technique.

\section{Research Variable}

In order to assess the relationship between variables in research, we must be able to identify each according to the type of relationship we expect to investigate (Hatch \& Farhady, 1982). They classify variables as independent and dependent variables.

The independent variable is the most important variable which we hope to investigate. This is the variable which is selected, manipulated, and measured by the researcher. The dependent variable, on the other hand, is the variable which we look at and measure to decide the effect of the independent variable. Since, in this study, the researcher wanted to check out the impact of his teaching on students' pragmatic competence, the pragmatic competence ratings of the students would be the dependent variable. Then, the practise using S.U.R.E Approach is the independent variable.

\section{Research Instrument}

The instrument is merely the tool to enable us to gather data, and it is prominent to select the best tool for the job. The determination of the data-collecting instrument depends on the purpose of the research about and the type of facts wished (Bell, 2005). Since the motive of this study was to identify the students' pragmatic competence, the researcher devised Discourse Completion Task (DCT), which is frequently used method in researches on pragmatics, as seen in (Jernigan, 2007; Baca, 2011); Reigle, 2011; Memarian, 2012; Brubaek, 2013). Although DCTs measure knowledge and do not permit direct estimations of real-world performance, they can be regarded as measuring manageable for performance, as information is conceivably a precondition for overall performance (McNamara \& Roever, 2006). The DCT employed in this study consisted of spoken communication situations adapted from Taguchi (2011) in which the learners produce spoken responses to the given scenarios and explain how the learners express themselves in different situations.

\section{Data Collection and Data Analysis}

This research employed a quantitative study using an approach of data collection namely pretest- posttest using DCT. Pretest was given before treatment while posttest 
was conducted after treatment. The pretest was aimed to examine the students' initial pragmatic competence. Then, the researcher administered some treatments using S.U.R.E as the approach of instruction. The posttest was conducted after administering the treatment to identify the influence of using S.U.R.E approach. The obtained test data were then analyzed utilizing SPSS V.24 and were interpreted to identify the enhancement of students' pragmatic competence.

\section{Scoring System}

The speech acts tested in DCT were assessed on their overall appropriateness, applying a five-point rating scale which is ranging from 1 to 5 (very poor to excellent) adopted from Taguchi (2011) as follows.

Table 1. Rating Scale

\begin{tabular}{|c|c|c|}
\hline Score & Grade & Interpretation \\
\hline 5 & Excellent & $\begin{array}{l}\text { Almost perfectly appropriate and effective in the level of directness, } \\
\text { politeness and formality }\end{array}$ \\
\hline 4 & Good & $\begin{array}{l}\text { Not perfect but adequately appropriate in the level of directness, } \\
\text { politeness, and formality. Expressions are a little off from target-like, but } \\
\text { pretty good. }\end{array}$ \\
\hline 3 & Fair & $\begin{array}{l}\text { Somewhat appropriate in the level of directness, politeness, and } \\
\text { formality, Expressions are more direct or indirect than the situation } \\
\text { requires. }\end{array}$ \\
\hline 2 & Poor & Clearly inappropriate, Expressions sound almost rude or too demanding. \\
\hline 1 & Very Poor & Not sure if the target speech act is performed \\
\hline
\end{tabular}

\section{Results}

Pretest posttest result and hypothesis are presented in the following tables.

Table 2. The Pretest-Posttest Score

\begin{tabular}{ccccc}
\hline No. & Students & Pretest Score & Posttest Score & N-Gain \\
\hline Mean & 2.76 & 3.61 & 0.39 \\
\hline
\end{tabular}

Table 3. Paired samples t-test

\begin{tabular}{|c|c|c|c|c|c|c|c|c|}
\hline & \multicolumn{5}{|c|}{ Paired Differences } & \multirow[t]{3}{*}{$\mathrm{t}$} & \multirow[t]{3}{*}{$\mathrm{df}$} & \multirow{3}{*}{$\begin{array}{l}\text { Sig. (2- } \\
\text { tailed) }\end{array}$} \\
\hline & \multirow[t]{2}{*}{ Mean } & \multirow[t]{2}{*}{$\begin{array}{c}\text { Std. } \\
\text { Deviation }\end{array}$} & \multirow[t]{2}{*}{$\begin{array}{l}\text { Std. } \\
\text { Error } \\
\text { Mean }\end{array}$} & \multicolumn{2}{|c|}{$\begin{array}{l}95 \% \text { Confidence } \\
\text { Interval of the } \\
\text { Difference }\end{array}$} & & & \\
\hline & & & & Lower & Upper & & & \\
\hline Pair 1 & -.85879 & .53882 & .09380 & -1.04985 & -.66773 & -9.156 & 32 & .000 \\
\hline
\end{tabular}




\section{Discussions}

This section discusses the results of the analysis being displayed. The results of the study are connected to the extant theories. Then, to hold the discussion, the research question and answer are formulated in harmony with its interpretations. To begin with, the research question has something to do with the effect of S.U.R.E. approach to promote students' pragmatic competence. The question is as follow. "Is the use of S.U.R.E. approach effective to enhance students' pragmatic competence?" The null hypothesis used as the tentative answer to that question states. "S.U.R.E. approach is not effective in enhancing students' pragmatic competence."

It can be observed from the obtained scores of pretest-posttest (see table 2) that the average scores of posttest to a certain extent is higher than that of pretest $(3.61>2.76)$. This shows that after the treatment, the students' pragmatic competence increases. Nevertheless, to see whether the increase is significant or not, a statistical test is administered. The analysis of normality test displayed in table 3 finds out that the sig value of pretest is 0.086 while the sig value of posttest is 0.200 . Since the values are more than 0.05 , it is assumed that the data of this study is normally distributed, therefore the next test that the researcher administered is paired sample t-test.

The analysis of paired sample t-test presented in table 4 finds out that the implementation of S.U.R.E. approach has positive impact to the students' pragmatic competence. That is, Asymp. Sig value was 0.000 with the significance level 0.05. The result is $0.00<0.05$, therefore significance value is lower than the significance level, so the null hypothesis is rejected. This implies that the present study proves that S.U.R.E Approach is effective in enhancing students' pragmatic competence.

The research result is connected to what Brock and Nagasaka (2005) claim that S.U.R.E. approach may help students see, use, review, and experience pragmatics. Hence, the students may at least have four benefits: 1) the students' awareness of pragmatic at work is raised by their teachers. Farahian, Rezaee, and Gholami (2012) state that teachers may help learners develop their pragmatic competence fostered with the help the learners accept from their teachers; 2) the students have a good chance to 
use English through small group activities. Jansson (2011) believes that group work is a good way to help the students practice expressing their thoughts in English and use words in situations when they are appropriate; 3) Students' pragmatic knowledge is reinforced through the common communicative events occurring daily in EFL classroom; and 4) the students experience and analyze language use in specific contexts such as by watching videos.

\section{Conclusion \& Recommendation}

Regarding the results and the statistical analysis of this study, it can be concluded that using S.U.R.E approach was effective in enhancing students' pragmatic competence. In addition, the statistical analysis in paired sample t-test showed that there was significant difference in mean score between students' pre-test and post-test. Due to its effectiveness, S.U.R.E approach can be devised as one of appropriate approaches in teaching pragmatic competence. Thence, the researcher would like to offer recommendations for English teachers and further researchers. Firstly, it is prominent for English teachers to keep developing activities of which EFL learners use English in context. The teachers should be more creative in providing materials and approaches so as to help the students being able to interact with others using English appropriately. Secondly, the researcher recommends other researchers interested in administering the similar study to include gender in their further research and provide more time allotment as well as a large number of participants.

\section{References}

Baca, E. (2011). Pragmatic Competence: The Case of Advice in Second Language Acquisition (SLA) Abroad. Arizona State University. Retrieved from https://repository.asu.edu/attachments/56685/content/Baca_asu_0010N_10711.pdf

Bell, J. (2005). Doing Your Research Project: A Guide for First-Time Researchers in Education, Health and Social Science (Fouth edit). England: Open University Press. Retrieved from http://elearning.ufl.udn.vn/home/esp/pluginfile.php/3274/mod_resource/content/1/J udith Bell - Doing_Your_Research_Project.pdf

Brewerton, P \& Millward, L. (2001). Organizational Research Methods: A Guide for Students and Researchers. London: SAGE.

Brock, Mark. N. \& Nagasaka, Y. (2005). Teaching Pragmatics in the EFL Classroom? Sure You Can! TESL Reporter, 31(1), 17-26. Retrieved from https://docplayer.net/22788686-Teaching-pragmatics-in-the-efl-classroom-sureyou-can.html

Brown, P. and Levinson, S. C. (1987). Politeness: Some Universals in Language Usage. 
Cambridge: Cambridge University Press.

Brubaek, S. (2013). Pragmatic Competence in the EFL Classroom. Universitetet I Oslo. Retrieved from https://www.duo.uio.no/bitstream/handle/10852/36653/MASTERxxhelexoppgavenx-x7xmarsx2013.pdf? sequence $=1 \&$ isAllowed $=\mathrm{y}$

Creswell, J. . (2003). RESEARCH DESIGN: Qualitative, Quantitative, and Mixed Methods Approaches. London: SAGE Publications.

Creswell, J. . (2014). Educational Research: Planning, Conducting and Evaluating Quantitative and Qualitative Research.Methods Approaches (Fourth Edi). Harlow: Pearson Education Limited. Retrieved http://basu.nahad.ir/uploads/creswell.pdf

Farahian, M., Rezaee, M., \& Gholami, A. (2012). Does Direct Instruction Develop Pragmatic Competence? Teaching Refusals to EFL Learners of English. Journal of Language Teaching and Research, 3(4), 814-821. Retrieved from http://www.academypublication.com/issues/past/jltr/vol03/04/30.pdf

Hamied, F. . (2017). Research Methods: A Guide for First-Time Researchers. Bandung: UPI Press.

Hatch, E. and Farhady, H. (1982). Research Design and Statistics for Applied Linguistics. Massachusetts: Newbury House Publisher.

Jernigan, J. E. (2007). Instruction and Developing Second Language Pragmatic Competence: An Investigation into the Efficacy of Output. Electronic Theses, Treatises and Dissertations. Retrieved from https://diginole.lib.fsu.edu/islandora/object/fsu:254202/datastream/PDF/download/ citation.pdf.

Jonsson, A. . (2011). For what purpose do language teachers use group work in their lessons?: A study of group work in the teaching of English, and modern languages, in a Swedish school. Säljö, Föreställningar Om Lärande Och Tidsandan, 71-72.

Liu, N. C. (2007). Pragmatics in Language Instruction: The Effects of Pedagogical Intervention and Technology on the Development of EFL Learners' Realization of Request. Texas A\&M University. Retrieved from https://oaktrust.library.tamu.edu/bitstream/handle/1969.1/ETD-TAMU2490/LIUmkjjjj-DISSERTATION.pdf?sequence=1\&isAllowed=y

McMillan, J.H and Schumacher, S. (2001). Research in Education: A Conceptual Introduction

McNamara, Tim \& Roever, C. (2006). The social dimension of proficiency: How testable is it? In Language testing: the social dimension (p. 43). https://doi.org/https://doi.org/10.1111/j.1467-9922.2006.00377.x

Memarian, P. (2012). The Use of Request Strategies in English by Iranian Graduate Students. Eastern Mediterranean University. Retrieved from https://pdfs.semanticscholar.org/6aed/97decee543e156f97ed96ad16fe088437f85.p df

Reigle, L. J. (2011). The Role of Pragmatic Competence in Second Language Acquisition. All Graduate Reports and Creative Projects. Utah State University. Retrieved from https://digitalcommons.usu.edu/cgi/viewcontent.cgi?article $=1167 \&$ context=gradre ports

Richard, J. C. (2006). Communicative Language Teaching Today (First edit). New 
York: Cambridge University Press.

Rueda, Y. . (2006). Developing Pragmatic Competence in a Foreign Language. Colombian Applied Linguistics Journal, (8), 1-14. Retrieved from http://www.scielo.org.co/pdf/calj/n8/n8a09.pdf.

Taguchi, N. (2011). Rater Variation in the Assessment of Speech Acts. Pragmatics Journal , International Pragmatics Association, 21(3), 453-471. Retrieved from https://journals.linguisticsociety.org/elanguage/pragmatics/article/download/3652/3 652-7139-1-PB.pdf

Tan, K.H and Farashaiyan, A. (2012). The Effectiveness of Teaching Formulaic Politeness Strategies in Making Request to Undergraduates in an ESL Classroom. Asian Social Science, 8(15), 1911-2025. https://doi.org/https://doi.org/10.5539/ass.v8n15p189

\title{
Conflict of Interest
}

No potential conflict of interest is reported

\begin{abstract}
About author
Dr. Dasep Suprijadi graduated from the English Education Study Program, School of Post Graduate Studies, Universitas Pendidikan Indonesia. At the moment he is a lecturer at undergraduate English Study Program of IKIP Siliwangi Bandung. He is interested in conducting research dealing with EFL teaching methods. He can be reached at suprijadi.dasep17@gmail.com
\end{abstract}

